\title{
Estimation of Residence Times and Recharge Area of Groundwater in the Moulares Mining Basin by Using Carbon and Oxygen Isotopes (South Western Tunisia)
}

\author{
Younes Hamed ${ }^{1}$, Moncef Zairi ${ }^{1}$, Wassim Ali $^{2}$, Hamed Ben Dhia ${ }^{1}$ \\ ${ }^{1}$ Ecole Nationale d'Ingénieurs de Sfax, Laboratoire: Eau, Energie et Environnement (L3E), Sfax, Tunisie; ${ }^{2}$ Karlsruhe Institut of \\ Technology (KIT), Karlsruhe University (Former) Institut of Applied Geosciences, Section Hydrogeology SMART Project \\ Coordination Team, Karlsruhe, Germany. \\ Email: hamed_younes@yahoo.fr, moncef.zairi@enis.rnu.tn, Hamed.Bendhia@uss.rnu.tn,wassim.ali@kiit.eddu
}

Received March $13^{\text {th }}, 2010$; revised September $1^{\text {st }}, 2010$; accepted September $8^{\text {th }}, 2010$.

\begin{abstract}
Radiogenic carbon $\left({ }^{14} \mathrm{C}\right.$ ) of the DIC (Dissolved Inorganic Carbon) and oxygen-18 were used to understand the hydrodynamic functioning of the multilayer aquifer system in the Moulares mining basin, southern Tunisia. The results of this study permits identify two groundwater types. A - an old paleoclimatic groundwater, marked by low carbon-14 $\left({ }^{14} \mathrm{C}\right)$ activities. $B$ - a recent groundwater, was distinguished by relatively high carbon-14 activities. In addition to these two water types, other groundwater, indicating a mixing effect, is resulting presumably from upward movement from the deeper groundwater. Based on ${ }^{14} \mathrm{C}$ activity and the piston flow type theory the groundwater residence time varies from 5 Kyear to 35 Kyear. Carbon-14 activity and oxygen-18 in Groundwater are active since Mio-Plio-Quaternary and Upper Cretaceous aquifers lead to the identification of paleorecharged water probably during Late Pleistocene and Early to Middle Holocene. The water feedings of these aquifers are mainly provided by infiltration of precipitations, infiltration of irrigation water, lateral feeding from cretaceous relieves from the South and the North and along recent and fossil drainage networks that constitute major fresh water sources in groundwater tables.
\end{abstract}

Keywords: Carbon and Oxygen Isotopes, Residence Time, Paleo-Recharge, South-Western Tunisia

\section{Introduction}

Southern Tunisia is dominated by arid and semi-arid climate conditions. Thus, main water supplies are pumped from groundwater. These resources are mainly located in Mio-Plio-Quaternary (MPQ) aquifer that provides over $85 \%$ of water supply for domestic consumption, irrigation and industrial use of the phosphates exploitation company (Compagnie de Phosphates de Gafsa - CPG). The second water resource is the upper Cretaceous aquifer named "Complexe Terminal" (CT).

The overexploitation of the MPQ aquifer in the Moulares mining basin within a total flow of $2500 \mathrm{l} / \mathrm{s}$ leads to a general piezometric drop of water level of around 0.7 $\mathrm{m} /$ year [1], artesian extinction and general dryness of springs in the region. These facts lead to continuous increase of water cost. Therefore, the MPQ shallow aquifer constitutes the most accessible water resources exploited with hundreds of shallow wells usually less than $50 \mathrm{~m}$. This aquifer is also overused by the phosphate industries of CPG within deep wells from 200 to $450 \mathrm{~m}$. The water consumption of the phosphate industries is estimated of around 45 Million $\mathrm{m}^{3} /$ year [2].

The establishment of the hydrodynamic system within the use of the classical hydrogeological tools is almost impossible for two reasons: 1) The actual disequilibrium of water dynamics consisting of overexploitation and 2) the structural reservoir complexity. For this reason, we tried to use isotopic study by $\left({ }^{13} \mathrm{C} /{ }^{14} \mathrm{C} \&{ }^{18} \mathrm{O}\right)$ to establish water dynamics in these aquifers and the mixing between the different water end members. Moreover, this method contributed to indentify respectively the age water relatively to recharging time and original characteristics. The water age determined by ${ }^{13} \mathrm{C} /{ }^{14} \mathrm{C}$ isotopes allows computing transit times, water speed and flowing rates, and the composition of water molecule allows to highlights possible phenomenon that affected the water such as evaporation or mixture. So, isotopic study improves our groundwater hydrodynamics understanding and contributes with classical hydrogeological tools to the charac- 
terization of the aquifer system.

In details, the aim of this paper is to identify the various sources of recharge and their relative residence times. The results will allow a better understanding of the water sources and mixing in the Moulares mining basin for viable long term groundwater development in the region.

\section{Geological Setting}

The Moulares syncline is situated in south-western Tunisia, between longitudes $8^{\circ} 00^{\prime}$ and $8^{\circ} 30 \mathrm{E}$ and between latitudes $34^{\circ} 15^{\prime}$, and $34^{\circ} 00^{\prime} \mathrm{N}$. This basin is limited by Algerian boarder to the west, by the Moulares-Gafsa fold belt (Bouramli, Bellil and Mrata Monts) to the north, and by the Metlaoui fold belt (Satah, Alima \& Bliji Monts) to the South. This basin cumulates has almost $270 \mathrm{Km}^{2}$ surface and is covered mainly by neogene sediments (Figure 1). The study area is characterized by arid to semi-arid climate with average precipitations of about $165 \mathrm{~mm} /$ year (Moulares Station). The evapotranspiration ratio is around $1680 \mathrm{~mm} /$ year [3]. The mean annual air temperature is about $23^{\circ} \mathrm{C}$ with a $4^{\circ} \mathrm{C}$ as a minimum in January and $42^{\circ} \mathrm{C}$ as maximum in August.

The drainage network is very dense (Figure 1) and mainly constituted by non-perennial valleys which collect surface run off from the surrounding hills of Moulares, Metlaoui ranges and the Algerian territories. Nevertheless, Tabeddit wady is characterized by permanent flow of water from phosphate mine waste lavatory in
Moulares and Redeyef towns. Surface water from these wadies is carried out to large continental depression of Chott El Gharsa to the South of the Moulares mining basin, and locally to the Garaat Douza depression in the eastern part of the study area (Figure 1).

The sedimentary series outcropping in the study area range from Cretaceous to Quaternary. In these series we can identify three (3) potential aquifer formations (Figures $2 \& 3$ ):

1) The Complex Terminal limestone aquifer which has an upper Cretaceous age;

2) The Miocene sandstone aquifer (Beglia formation);

3) The Pliocene to Quaternary conglomeratic sandstone and clays aquifer (Segui formation);

The aquifer system of CT covers the major part of South Tunisia and the northern Sahara (Algeria, Tunisia and Libya, approximately $250,000 \mathrm{Km}^{2}$ ) [4]. The upper Cretaceous aquifer is confined. It is mainly drained through several springs, which follow the ranges with a flow varying between 2 and $15 \mathrm{l} / \mathrm{s}$. This reservoir is characterized by fractured limestone locally suffering dissolution and grading to karstic system, which is frequent in Gafsa basin [5]. This fractured limestone reservoir is around $500 \mathrm{~m}$ thick and constitutes important water resources in the region.

The Miocene aquifer is generally sub-confined. It is considered as the principal hydraulic system of the Moulares mining basin. The reservoir consists of friable massive sands with cross stratifications interbeded with thin

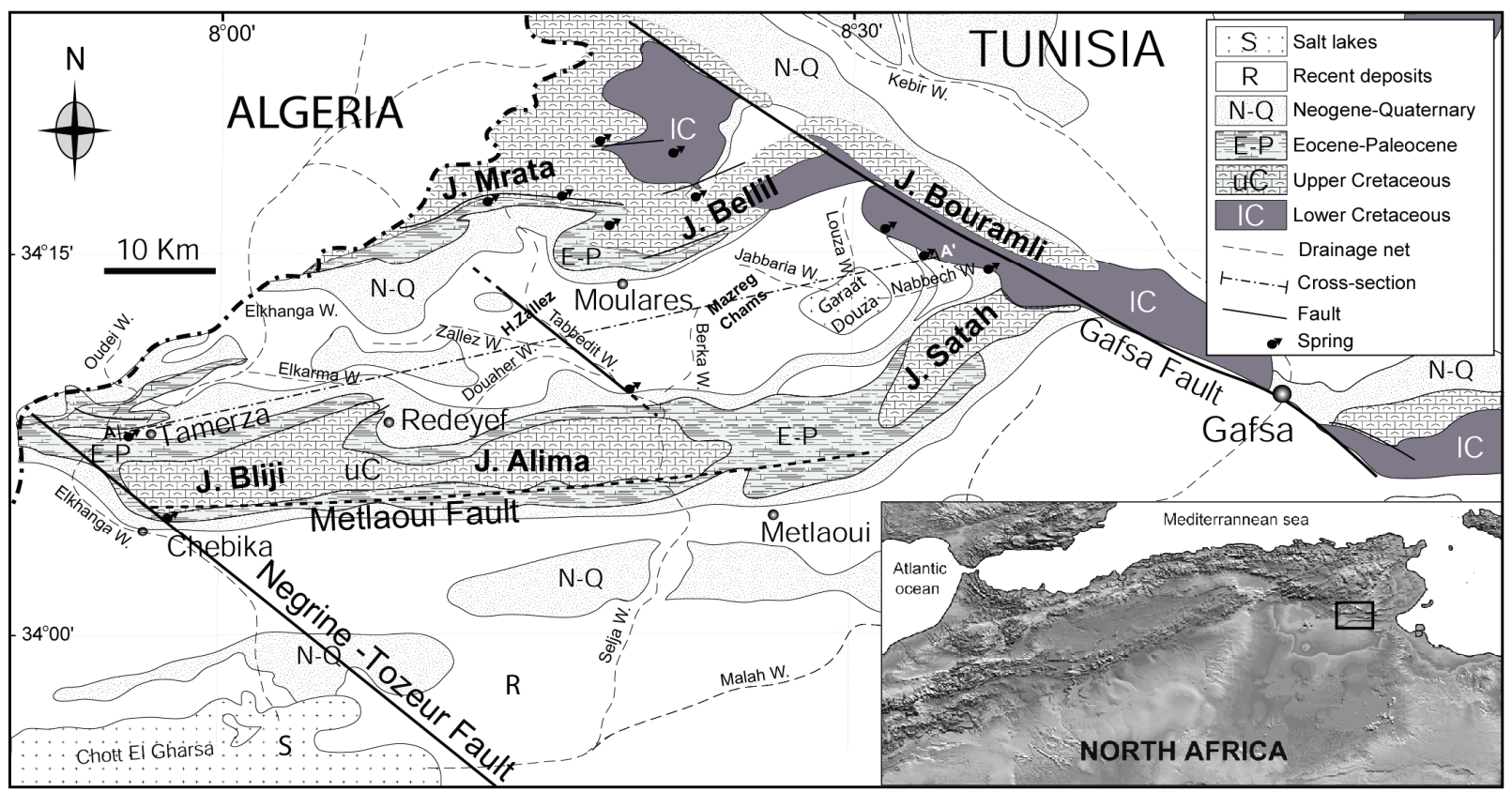

Figure 1. Geological map of the Moulares mining basin. 


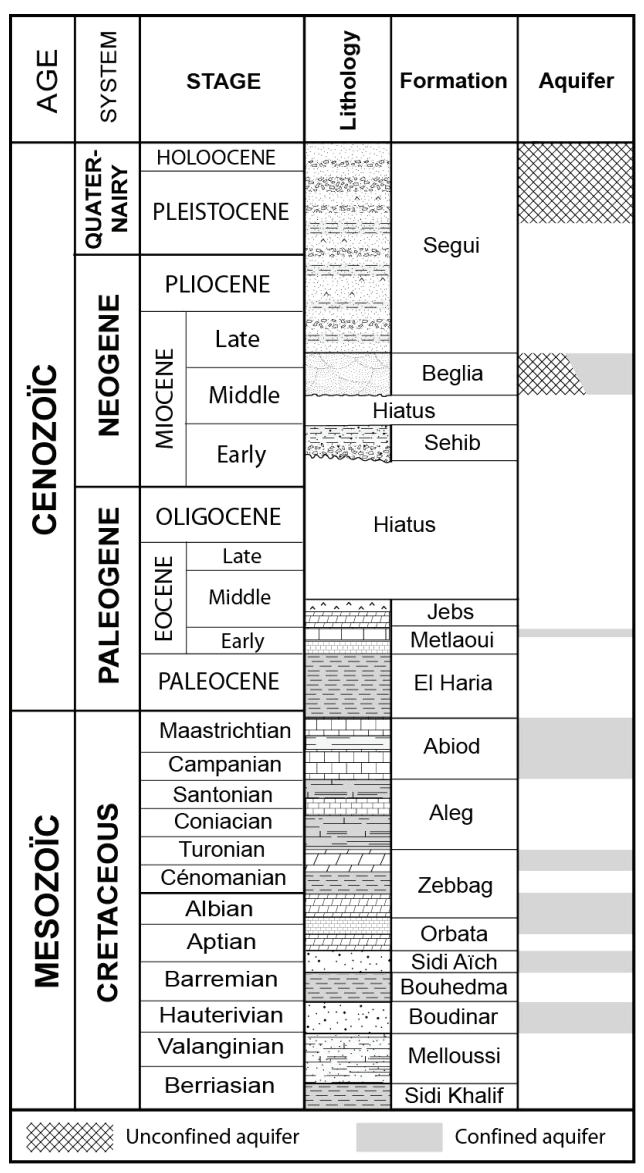

Figure 2. Lithostratigraphic column of the study area.

red-brown claystone layers. This Beglia formation is exploited within 23 deep wells at total depth varying from 225 to $450 \mathrm{~m}$ and 160 surface wells with depth shallower than $45 \mathrm{~m}$. The Plio-Quaternary aquifer is mainly unconfined and covers almost all the Moulares eastern basin and the western part of Tamerza basin. This reservoir consists of sands and claystone layers with two major gypsum intercalations to the base and to the top of this series. This facies is interpreted as the result of important periods of aridification. The relative position of the two evaporite intercalations can be ascribed perfectly to the two well-known major climatic crisis during the Messinian (5, 3 to 6,5 Ma) and the villafranchian $(2,4$ Ma) [6]. This aquifer is exploited by 14 deep wells and 605 surface wells.

The transmissivity of the Miocene and the PQ aquifers ranges from $18.7 \times 10^{-4} \mathrm{~m}^{2} \cdot \mathrm{s}^{-1}$ to $54 \times 10^{-4} \mathrm{~m}^{2} . \mathrm{s}^{-1}$ and 0.33 $\times 10^{-4} \mathrm{~m}^{2} \cdot \mathrm{s}^{-1}$ to $53 \times 10^{-4} \mathrm{~m}^{2} \cdot \mathrm{s}^{-1}$ respectively. The permeability is varying between $2 \times 10^{-4}$ and $6 \times 10^{-4} \mathrm{~m} \cdot \mathrm{s}^{-1}$ in Beglia formation and it is between $1.16 \times 10^{-4}$ and $2 \times$ $10^{-4} \mathrm{~m} . \mathrm{s}^{-1}$ in Segui formation [7]. These ranges depend essentially on the depth of aquifers and on the heterogeneity of their lithofacies. Other early cretaceous reservoirs are not exploited considering their bad water quality and their very important depth such as The Zebbag limestone, The Sidi Aïch and Boudinar sandstones. The groundwater flow directions of the MPQ aquifers follow generally the surface water flowing (N-S). In fact, they are discharged into Chott El Gharsa and Garaat Douza salt lakes (Figure 4). The word "Chott" is a North African term for a salt flat within a hydrologically closed basin [8].

In the PQ aquifer, located in the eastern and in the western part of the basin, the groundwater flow converges from all directions to the endoreic depression of Garaat Douza and Chott El Gharsa which constituted the natural discharge area of this reservoir (Figure 4). While, in the Miocene aquifer two flow directions are observed. These flow directions are separated by a groundwater divide located in the Henchir Zallez and the Mazreg Chams zone, in the north of Redeyef town. The first groundwater flow is NE-SW, from the hills of Moulares range towards the Tamerza springs which represent the natural drainage system of this aquifer. The second flow direction are NW-SE, from the groundwater divide of the Henchir Zallez zone; and NE-SW, from the groundwater divide of the Mazreg Chams zone towards the Selja wady in the overexploited Berka region (Figures $3 \& 4$ ). Concerning the upper Cretaceous aquifer, exploited only by springs, the Carbon-14 dating shows low activities to the south of the basin and high activities to the north, which suggest a general groundwater flow probably Noth-South toward Chott El Gharsa depression through hydraulic sill of Selja and Tamerza.

The study zone belongs to the southern Atlas fold belts. This region is affected by fault network and thin skin tectonics characterized by fault related folds [9]. The hydrodynamics of these aquifer systems are closely influenced by tectonics [10]. Thus, the basin is controlled by the major NW-SE fault system such as Gafsa, Tabeddit and Negrine-Tozeur faults $[9,10]$, as well as the EastWest fault system such as the Metlaoui faults [9].

\section{Methodology}

Twenty five groundwater samples (11 deep wells, 8 surface wells, 5 springs and 1 from Foum El Khangua Dam) have been collected during 2005 (Figure 4 and Table 1). Radiocarbon analyses were carried out at the Laboratory of Radio-Analyses and Environment/National Engineering College of Sfax (Tunisia), by scintillation counting on $\mathrm{C}_{6} \mathrm{H}_{6}$ synthesized from $\mathrm{BaCO}_{3}$ stripped in the field from 1501 water samples. Results are reported in per- 


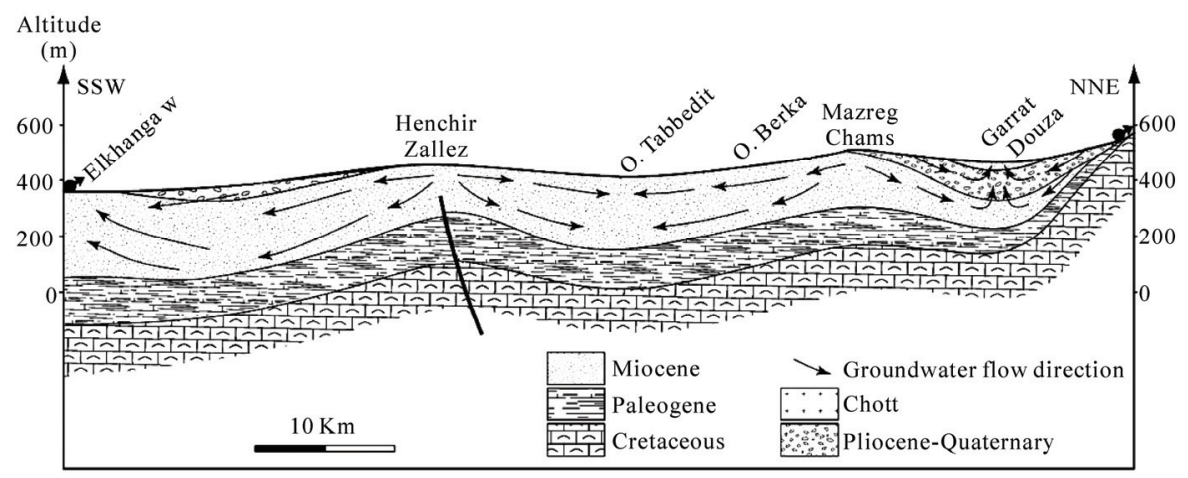

Figure 3. Cross section of the Moulares mining basin (NNE-SSW).

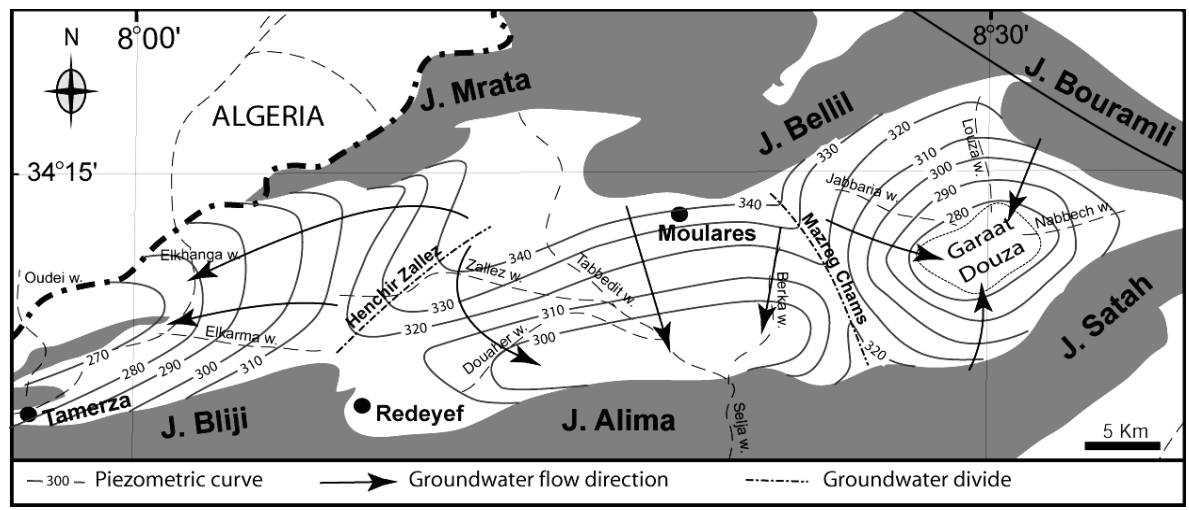

Figure 4. Piezometric map of groundwater in Moulares mining basin.

centage of modern carbon (pmC) [11].

For financial constraints, a limited number (19) of groundwater samples have been selected for isotopic analysis (oxygen-18), using mass spectrometer techniques (Table 1). Standard $\mathrm{CO}_{2}$ equilibration and Zinc reduction technique $[12,13]$ have been employed respecttively for ${ }^{18} \mathrm{O}$ analysis preparation. All oxygen isotopes analysis are reported in the usual $\delta$ notation relative to Vienna Standard Mean Oceanic Water (VSMOW) standard, where $\delta=\mathrm{RS} / \mathrm{RSMOW}$ )-1] $\times 1,000$; RS represents either the ${ }^{18} \mathrm{O} /{ }^{16} \mathrm{O}$ ration of the sample, and RSMOW is either the ${ }^{18} \mathrm{O} /{ }^{16} \mathrm{O}$ ration of the Standard Mean Oceanic Water. Typical precision is $\pm 0.2 \%$ for the oxygen-18.

Carbon-14 activity of groundwater of Moulares mining basin varies between 3 and $59.4 \mathrm{pmC}$ in the deep wells of H. Gallel (7) and of Mazreg Chams (15), between 16 and $75.3 \mathrm{pmC}$ in surface wells of Ali Ben Salah (8) and of Ali Messaoui (14), between 17.5 and 67.2 pmC in the springs of Chebika (24) and of Tamerza (20) and it is around 48 pmC in Foum El Khangua Dam (25) [14]. The spatial distribution of ${ }^{14} \mathrm{C}$ activity of groundwater in MPQ aquifers of Moulares mining basin (Fig- ure 5) shows a good correlation with the piezometric data $[14,15]$. Hence, we observe ${ }^{14} \mathrm{C}$ activity decrease along groundwater flow direction. In the Moulares Eastern basin (PQ), low ${ }^{14} \mathrm{C}$ activities are recorded in the deep wells $(1,5,6 \& 7)$ and indicates very old water dating from 18.66 till $27.91 \mathrm{ky} \mathrm{BP}$ apparent ages. This water is probably coming from lower sandy reservoir of the Plio-Quaternary or from the Beglia formation by upstreaming through sandy claystone layers that are between 50 to $200 \mathrm{~m}$ thick. This hypothesis is argued by the overexploitation of this aquifer. The highest activities (44 and $62 \mathrm{pmC}$ ) are observed in the surface wells of Rahem Elakrmi (3) and of $\mathrm{M}^{\text {ed }} \mathrm{B}$ Gayed (4) located in the north of this basin. These activities indicate recent water characterized by apparent age between 3.80 and $6.04 \mathrm{ky}$ BP. As such, in western Moulares basin (M) ${ }^{14} \mathrm{C}$ activeties are around $75 \mathrm{pmC}$ in the surface wells of $\mathrm{M}^{\text {ed }}$ Barhoumi (11) and of Ali Messaoui (14) located upstream of Tabeddit wadi. But, this activity is around $33 \mathrm{pmC}$ in the surface well of Salem Mabrouki (12) located in downstream of this perennial wadi by the dumping of Industrial and domestic wastes. This decrease of activity northwards the fault and range of Metlaoui is probably due to the hydraulic barrier. It argues the important con- 
Table 1. Isotopic data of the sampled groundwater in the Moulares mining basin.

\begin{tabular}{|c|c|c|c|c|c|c|}
\hline Well name & $\mathrm{N}^{\circ}$ & depth (m) & Activity (pmC) & App.age (y.BP) & ${ }^{13} \mathrm{C}(\%)$ & ${ }^{18} \mathrm{O}(\%$ vs SMOW $)$ \\
\hline \multicolumn{7}{|l|}{$\underline{\text { Plio-Ouaternary }}$} \\
\hline Channoufia II & 1 & 398 & $10 \pm 0.8$ & $18662 \pm 636$ & -5.68 & -8.28 \\
\hline Rmel & 2 & 50 & $46.5 \pm 1.2$ & $6154 \pm 203$ & -6.32 & -7.39 \\
\hline Rahem Elakrmi & 3 & 28 & $44.2 \pm 0.7$ & $6043 \pm 122$ & $* * *$ & -7.83 \\
\hline $\mathrm{M}^{\text {ed }}$ b Gayed & 4 & 33 & $62.3 \pm 1.3$ & $3803 \pm 167$ & -5.04 & -7.76 \\
\hline Nazia & 5 & 203 & $8.20 \pm 0.65$ & $20090 \pm 668$ & -4.98 & -7.94 \\
\hline Jabbria I & 6 & 206 & $8 \pm 0.65$ & $20284 \pm 654$ & -5.94 & -7.77 \\
\hline H.Gallel & 7 & 266 & $3 \pm 0.85$ & $27917 \pm 218$ & -6.03 & -7.96 \\
\hline Ali B Salah & 8 & 37.5 & $16 \pm 0.9$ & $14949 \pm 470$ & -6.07 & -7.8 \\
\hline \multicolumn{7}{|l|}{ Miocene } \\
\hline Berka 4 & 9 & 325 & $35 \pm 1.3$ & $6475 \pm 552$ & $* * *$ & -7.83 \\
\hline Mratta II & 10 & 234 & $59 \pm 1.1$ & $4270 \pm 159$ & -8.63 & -6.82 \\
\hline $\mathrm{M}^{\text {ed }}$ Barhoumi & 11 & 6 & $75 \pm 1.3$ & $2274 \pm 136$ & $* * *$ & -7.73 \\
\hline Salem Mabrouki & 12 & 7 & $33 \pm 1.7$ & $8859 \pm 408$ & $* * *$ & -7.33 \\
\hline Tarfaya 8 & 13 & 440 & $3,4 \pm 1.2$ & $37290 \pm 242$ & -5.3 & -8.29 \\
\hline Ali Messaoui & 14 & 23 & $75.3 \pm 1.2$ & $2280 \pm 127$ & $* * *$ & -6.36 \\
\hline Mazreg chams & 15 & 205 & $59.4 \pm 1.6$ & $4185 \pm 214$ & -9.83 & -7.03 \\
\hline F. O. Sardouk & 16 & 231 & $36 \pm 1.1$ & $8170 \pm 256$ & -9.91 & -7.12 \\
\hline Mides $2^{*}$ & 17 & 26 & $45 \pm 1$ & 6601 & -5.5 & $* * *$ \\
\hline F. Elkhangua $1^{*}$ & 18 & 138 & 18 & 14176 & -11.3 & $* * *$ \\
\hline Rechig* & 19 & 250 & 24.7 & 11560 & -9.68 & $* * *$ \\
\hline S. Tamerza $3 *$ & 20 & Spring & 67.2 & 3286 & -8.56 & $* * *$ \\
\hline \multicolumn{7}{|l|}{$\underline{\text { Upper Cretaceous }}$} \\
\hline Aïn Gatâa & 21 & Spring & $61.4 \pm 1.2$ & $3913 \pm 156$ & -8.18 & -6.74 \\
\hline Aïn Ras El Mâa & 22 & Spring & $63 \pm 1.2$ & $3757 \pm 158$ & -7.8 & -6.33 \\
\hline Aîn Wssaeif & 23 & Spring & $28.6 \pm 0.9$ & $10059 \pm 260$ & -7.39 & -6.8 \\
\hline S. Chebika* & 24 & Spring & 17.5 & 14409 & -4.5 & $* * *$ \\
\hline F Khangua Dam* & 25 & $* * *$ & 48 & 6067 & -7.56 & $* * *$ \\
\hline
\end{tabular}

tribution of deep water by vertical ascending drainance of old water from deeper aquifers or lower part of shallow aquifer to upper layers. Another way is recharging effect of Tabeddit wadi could also explain this old water. This reason is confirmed by the high permeability $6.10^{-4}$ $\mathrm{m} / \mathrm{s}$ [16] issued from good lithology (sand) and shallow well (less than $6 \mathrm{~m}$ ). Moreover, there is a great amount of Cadmium, Fluor and salinity which confirm this descending streaming [7].

However, downstream of this hydraulic barrier (fault 


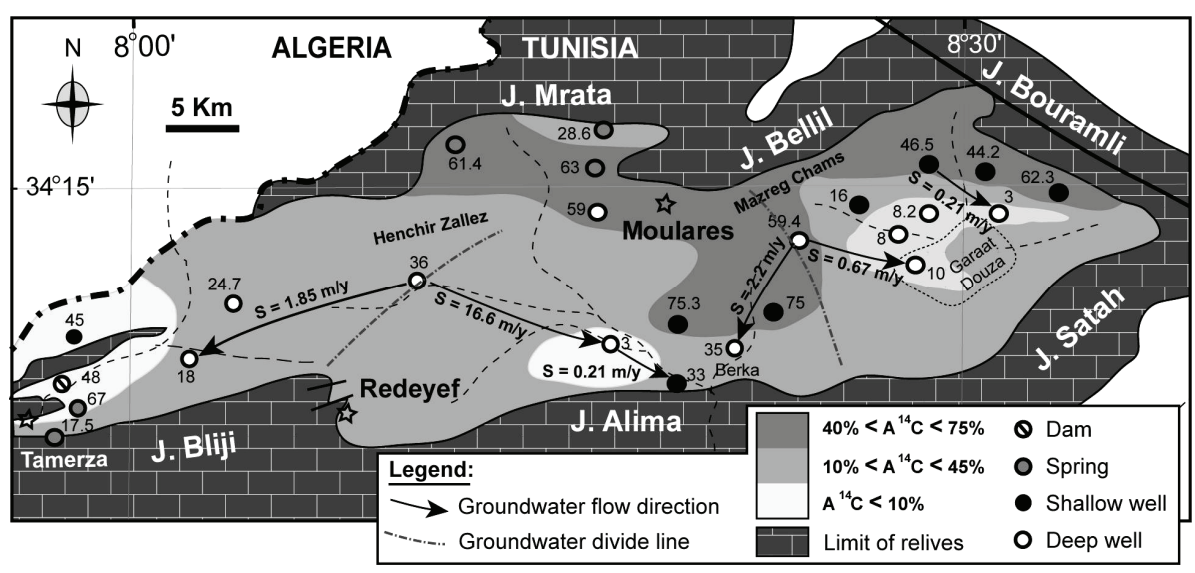

Figure 5. Spatial distribution of ${ }^{14} \mathrm{C}$ activity of groundwater in the Moulares mining basin.

and range of Metlaoui), a recent groundwater distinguished by relatively high carbon-14 activities is observed in surface wells (Chott region in the South) [14]. Therefore, we argue for the discontinuity between the Moulares mining basin and the Chott basin. The only communication between these two basins is through the alluvial aquifer of Berka-Tabeddit, using the Selja wadi prolongement of Tabeddit wadi. One of these examples of ascending drainance is the "Continental Intercalaire" (CI) aquifer to the "Complexe Terminal" (CT) in the Tozeur basin in the South of Moulares mining basin [16], in which tectonics has played important role. Recently, the same phenomenon is observed in Niger in the Irhazer plain a long the major fault of Inourarm [16] and in NW of Tunisia (Kef region) [17].

Concerning deep wells, the map shows a good spatial distribution of carbon-14 activities with the groundwater flow directions. However, the carbon-14 activity decreases relatively to the flow direction. But in the western Tamerza basin, we observe an increase of carbon-14 activity in Mides region to the sill of Tamerza. It is around $45 \mathrm{pmC}$, in the surface well of Mides 2 (17) drained by alluvial aquifer of Miocene (M), to $67.2 \mathrm{pmC}$ in the Tamerza Spring (20). However, Foum ElKhangua Dam (25) shows an intermediate activity around $48 \mathrm{pmC}$. This repartition of ${ }^{14} \mathrm{C}$ activities has not concordance with the hydrogeological data. Thus, carbon-14 activities do not decrease along the groundwater flow direction. Many hypotheses can be supposed to interpret this non-conformity:

- The possibility of rejuvenation of Miocene aquifer water by irrigation returns in Tamerza oasis [14];

- The phenomenon of hydrodispersion observed in the sandy aquifers shows the decrease of ${ }^{14} \mathrm{C}$, not only in one direction, but also in many directions with different speed due to the heterogeneity of lithology and sand structure [18];

- The phenomenon of non-proportionality between the geological reserves and the lower of outlet flow;

- The possible hypothesis is the dilution by Foum El Khangua Dam water (20) that shows an evaporated and recent water [14];

The speed and groundwater flow direction estimation (Figure 4) is based on the "piston flow" type transfer. The difference of transit time between two points A and $\mathrm{B}$ of aquifer a long groundwater flow direction is given by the following formula [19]:

$$
t_{B}-t_{A}=\left|\left(T_{1 / 2} / \operatorname{In} 2\right) \times \operatorname{In}\left(A_{B} / A_{A}\right)\right|
$$

$t_{A}-t_{B}$ : residence or transit time between $A$ et $B$ per year.

$T_{1 / 2}:{ }^{14} \mathrm{C}$ period $=5730$ years.

$A_{A} / A_{B}$ : activity measured in $A$ and $B$.

The estimation of groundwater flow direction speed in PQ aquifer between the deep well of Mazreg Chams (15) $(59.4 \mathrm{pmC})$ and the deep well of Channoufia II (1) (10 pmC) $10 \mathrm{Km}$ far from each other, is around $0.67 \mathrm{~m} /$ year. However, it is around $0.21 \mathrm{~m} /$ year between the surface well of Rmel (2) (46.5 pmC) and the deep well of Hanchir Gallel (7) (3 pmC). These two latter wells are $5 \mathrm{Km}$ far from each other. In the Miocene aquifer, the groundwater speed and flow direction between the deep well of Mazreg Chams (15) (59.4 pmC) and the deep well of Berka 4 (9) $(35 \mathrm{pmC}) 10 \mathrm{Km}$ far from each other, is around $2.22 \mathrm{~m} /$ year. It is around $16.6 \mathrm{~m} /$ year between the deep well of O.Sardouk (16) (36 pmC) and the deep well of Tarfaya 8 (13) (3 pmC) $11.5 \mathrm{Km}$ between them. The high speed groundwater is facilated by the Tabeddit fault (Figure 1). Close to the hydraulic barrier (fault and range of Metlaoui) the groundwater flow direction decrease considerably to attain $0.21 \mathrm{~m} / \mathrm{y}$ between the deep well of 
Tarfaya 8 (13) (3 pmC) and the shallow well of Salem Mabrouki (12) (33 pmC) $2.5 \mathrm{Km}$ far from each other.

Once blocked by the hydraulic barrier, the deep aquifer of upper Cretaceous can be surely found in artesian condition. Thus, this idea is confirmed by high debit of springs of $\mathrm{UC}(\approx 40 \mathrm{l} / \mathrm{s})$ and the water migration to the superficial layers. This difference of hydraulic charge and the overexploitation of the Miocene aquifer in Berka zone, essentially by the deeper wells of CPG $(\approx 500 \mathrm{l} / \mathrm{s})$ caused this migration of groundwater. In fact, the old deep water are detected in the shallow well of Salem Mabrouki (12) showing an apparent age of around 8.85 Ky BP with carbon-14 activity around 33 pmC. Nevertheless, that value of ${ }^{14} \mathrm{C}$ activity does not reflect pure old water, melted by a recent recharge. But in $\mathrm{M}^{\text {ed }}$ Barhoumi shallow well (11) located in the upstream of Metlaoui fault and Tabeddit wadi, that shows an apparent age of around $2.27 \mathrm{Ky} \mathrm{BP}$ with ${ }^{14} \mathrm{C}$ activity around $75 \mathrm{pmC}$. This indicates the absence of any contribution of old water belonging to deep aquifer (ascending drainance). So, this idea confirms the blockage of groundwater flow direction by the hydraulic barrier.

The calculations of speed groundwater flow represented only a little estimation. This may be due to eventual errors in results of mixing phenomena and/or eventual to opening system, which clearly show the role played by the Metlaoui fault as a hydrological barrier, originating the discontinuity between the Moulares mining basin in the north and the Chott basin in the south. In the western part of the basin, the speed of groundwater flow is around $1.85 \mathrm{~m} /$ year observed between the deep well of O. Sardouk (16) (36 pmC) and the deep well ElKhangua 1 (18) $(18 \mathrm{pmC}) 14 \mathrm{Km}$ far from each other. This shows an evidenced flow direction to the sill of Tamerza towards ElGharssa Chott.

Measured ${ }^{14} \mathrm{C}$ activities in the selected well samples which range between 3 and $75.3 \mathrm{pmC}$ (Table 1) confirm the mixing effect between "old" and the relatively recent groundwater poles (Figure 6). The ancient groundwater pole $(1,5,6,7,8 \& 22)$ of the PQ and UC aquifers is characterized by enrichment of mineral carbon and deficiency of organic carbon and by the lowest carbon- 14 activities varying between 3 and $17 \mathrm{pmC}$. This groundwater is likely recharged during the late Pleistocene and the early Holocene periods under cooler climatic regime. However, the relatively recent groundwater pole $(16,21$, $23 \& 24)$ is marked by enrichment of organic carbon and deficiency of mineral carbon and by high quantity of ${ }^{14} \mathrm{C}$ activity (59 and $67.2 \mathrm{pmC})$. This groundwater is interpreted as contemporaneous recharge at the high altitude surrounding mountains. Between the two poles, we can observe another pole $(2,4,15,17,18,19,20 \& 25)$ characterized by mixing groundwater. This groundwater is resulting from the two types of mineral and organic carbon. These results are also confirmed by the diagram $\mathrm{A}^{14} \mathrm{C} v s \delta^{18} \mathrm{O}$ (Figure 7). Referring to isotopic study of the ingredients of water molecule $\left({ }^{18} \mathrm{O} \&{ }^{2} \mathrm{H}\right)$, done in South Tunisia $[7,14,21,22]$, it seems that there is differences in isotopic composition between the groundwater and actual precipitation. Data from the nearest Global Network for Isotopes in Precipitation (GNIP) station (6075000), located in Sfax city, south-eastern Tunisia, weighed mean $\delta^{18} \mathrm{O}$ and $\delta^{2} \mathrm{H}$ values of -4.60 and -23.30 $\%$ vs SMOW, respectively [20]. These values of local precipitation are much higher than those supposed for the upper Cretaceous groundwater, indicating either a recharge altitude effect or a palaeoclimatic effect (recharged under colder climatic conditions than at present).

Based on the radiogenic carbon activities in the DIC (Dissolved Inorganic Carbon) and oxygen-18, the use of

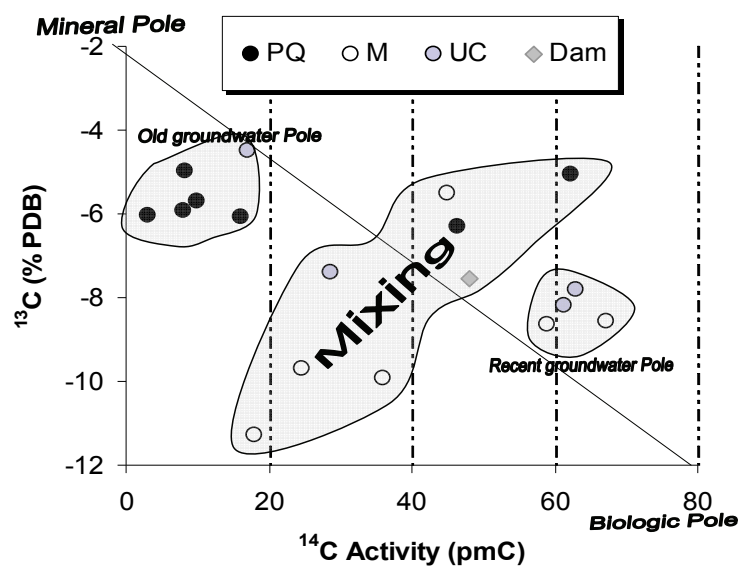

Figure 6. Activity ${ }^{14} \mathrm{C} /{ }^{13} \mathrm{C}$ relationship.

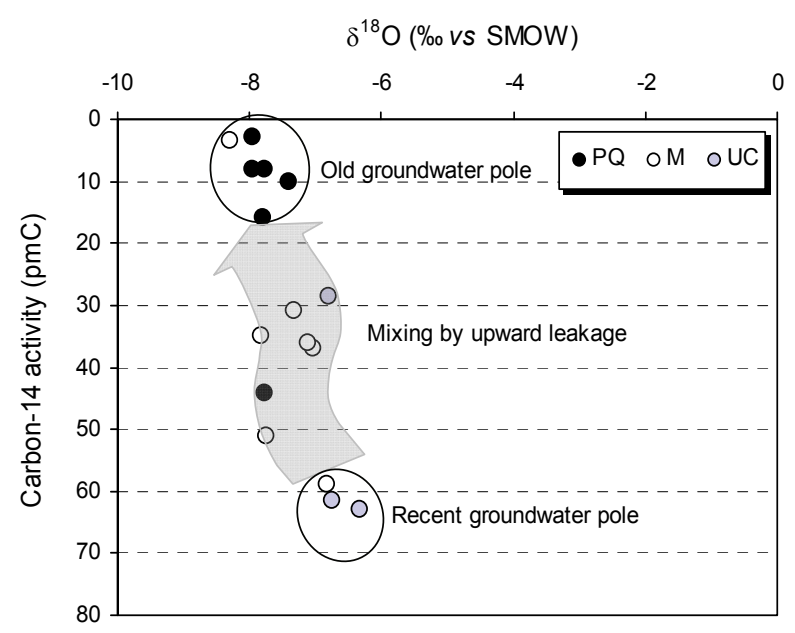

Figure 7. $\delta^{18} \mathrm{O} /$ Activity ${ }^{14} \mathrm{C}$ relationship. 
isotopic methods to study the functioning of the groundwater aquifer system in the Moulares mining basin has been very effective. This study shows that recharging basin is in high altitude surrounding mountains characterized by big fracture limestone and karstic system (Figure 2) and by the two zones of Hanchir Zallez in the western and the Mazreg Chams in the east that have caused a separation of groundwater flow direction in the basin. These results are confirmed by the last hydrochemical, geophysical and lithostratigraphic study in the basin [21-26] and actually by this isotopic data.

\section{Conclusions}

The use of isotopic methods to study groundwater recharge sources and mixing in the Moulares mining basin has been demonstrated to be well suited for these purposes and showed good results. Based on the radiogenic carbon activities and oxygen-18, it is possible to distinguish various types of water and mixing processes in the system:

- an "old" water marked by low ${ }^{14} \mathrm{C}$ activities and by impoverishment of ${ }^{18} \mathrm{O}$. This groundwater component is interpreted to be recharged during the late Pleistocene to early Holocene period under a cooler and humid climatic regime;

- a "native" water marked by high ${ }^{14} \mathrm{C}$ activities and by enrichment of ${ }^{18} \mathrm{O}$, located mainly in the north part of the basin suggesting a recharge period as early as post nuclear bomb tests period (1952) at the high altitude surrounding mountains (Oriental Atlas and Saharan Atlas);

- a "mixing" groundwater located in the south part of the basin. This groundwater resulting from the dominant upward leakage from the deep upper Cretaceous artesian water table. The natural and anthropic seismic activity and the permanent groundwater flow of Tabeddit wadi and the dam reservoir water, contribute all in this mixing of groundwater;

This isotopic study contributes to a better understanding of the sources, times of recharge and mixing processes occurring once infiltration reaches the water table.

\section{REFERENCES}

[1] A. Choura et Y. Hamed, "Actualisation du Bilan des Nappes du Bassin Minier de Moulares-Redayef," RAP International, DGRE, 2010.

[2] Y. Hamed, "Effet de la Pollution Industrielle sur les Ressources Hydriques Dans le Bassin Minier de Gafsa Sud (Sud Ouest Tunisien)," La 2ème Edition du Congrès International Eaux, Déchets et Environnements-Union des Pays de la Méditerranée - El Jadida, Maroc, 2009.
[3] M. Yermani, K. Zouari, J. L. Michelot, A. Mamou and L. Moumni, "Approche Géochimique du Fonctionnement de la Nappe Profonde de Gafsa Nord (Tunisie centrale)/ Geo-Chemical Approach to the Functioning of the Gafsa North Deep Aquifer (Central Tunisia)," Hydrology Science Journal, Vol. 48, No. 1, 2003, pp. 95-108.

[4] OSS. "Système Aquifere du Sahara Septentrional. Observatoire du Sahara et du Sahel," TechRep, Tunis, 2003, pp. 9973-856.

[5] M. Henchiri and N. Slim-S'Himi, "Silicification of Sulphate Evaporites and Their Carbonate Replacements in Eo- cene Marine Sediments," Two Diagenic Trends, Sedimentology, Tunisia, 2006, pp. 1-25.

[6] R. Ahmadi, "Utilisation des Marqueurs Morphologiques, Sédimentologiques et Microstructuraux Pour la Validation des Modèles Cinématiques de Plissement. Application à l'Atlas Méridional Tunisien, Thèse

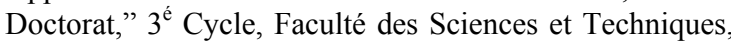
Nantes, 2006, p. 200.

[7] Y. Hamed, "Caractérisation Hydrogeologique, Hydrochimique et Isotopique du Systeme Aquifere du Synclinal de Moularès-Tamerza (Sud Ouest Tunisien)," Ph.D Thesis, University of Sfax, 2009.

[8] C. Swezy, "The Role of Climate in the Creation and Destruction of Continental Stratigraphic Records: An Example from the Northern Margin of the Sahara Desert," SEPM (Society for Sedimentary Geology), Special Publication, Vol. 77, 2003, pp. 207-225.

[9] R. Ahmadi, J. Ouali, E. Mercier and J. L. Mansy, "The Geo-Morphologic Responses to Hinge Migration in the Fault-Related Folds in the Southern Tunisian Atlas," Journal of Structural Geology, Vol. 28, No. 4, 2006, pp. 721-728.

[10] F. Zargouni, "Tectonique de l'Atlas Méridional de Tunisie. Evolution Géométrique et Cinématique des Structures en Zones de Cisaillement, Thèse Doctorat des Sciences," Université de Louis Pasteur de Strasbourg, France, 1985.

[11] M. Stuiver and H. Polach, "Reporting of ${ }^{14} \mathrm{C}$ Data," International Journal of Radiocarbon, Vol. 19, 1977, pp. 355-363.

[12] M. L. Coleman, T. J. Shepherd, J. J. Durham, J. E. Rouse, G. R. Moore, "Reduction of Water with Zinc for Hydrogen Isotope Analysis," Analytical Chemistry, Vol. 54, 1982, pp. 993-995.

[13] S. Epstein and T. K. Meyada, "Variations of ${ }^{18} \mathrm{O}$ Content of Waters from Natural Sources," Geochimica et Cosmochimica Acta, Vol. 4, No. 5, 1953, pp. 213-224.

[14] B. Abidi, "Caractérisation Hydrogéologique, Géochimique et Isotopique des Systèmes Aquifères du Synclinal de Tamerza et de la Plaine de Chott El Gharsa (Sud Ouest Tunisien), Thèse Doctorat," Université de Sfax, 2007.

[15] M. Chalbaoui, "Vulnérabilité des Nappes Superficielles Subaffleurantes du Sud-Ouest de la Tunisie," Sécheresse, Vol. 11, No. 2, 2000, pp. 85-91. 
[16] A. Mamou, "Etude Géologique et Hydrogéologique de la Région de Tamerza (Sud-Ouest Tunisien). Possibilité de Création de Retenues Souterraines au Nord du Jebel El Ardhia, Thèse Doctorat de 3 é Cycle," Université Scientifique et Médicale de Grenoble, France, 1981.

[17] Y. Hamed, "Caractérisation Hydrogéologique, Hydrochimique et Isotopique des Eaux Souterraines de la Région du Kef (Nord Ouest Tunisien). Mémoire DEA," Faculté des Sciences de Sfax, 2004.

[18] K. P. Seiler, "Man's Impact on Groundwater Systems. Environmental Isotopes in the Hydrological Cycle," Principles and Applications, Volume 5, 2000.

[19] J. C. Fontes, "Isotopes du Milieu et Cycles des Eaux Naturelles: Quelques Aspects, Thèse, Doctorat des Sciences," Pierre et Marie Curie Paris VI, France, 1976.

[20] GNIP, "Global Network for Isotopes in Precipitation," The GNIP Database, Release 3, October 1999. http:// www.iaea.org/programs/ri/gnip/gnipmain.htm

[21] J. Andrews, W. Edmunds, P. Smedley, J. Fontes, L. Fifield and G. Alla, "Chloride 36 in Groundwater as a
Palioclimatic Indicator: The East Midlands Triasic Sandstone Aquifer (UK)," Earth and Planetary Science Letters, Vol. 122, 1994, pp. 159-171.

[22] S. Kamel, Y. Hamed, N. Chkir and K. Zouari, "The Hydro Geochemical Characterization of Ground Waters in Tunisian Chott's Region," Evironmental Geology, Vol. 54, No. 4, 2007, pp. 843-857.

[23] A. Maliki, "Etude Hyrogéologique, Hydrochimique et Isotopique du Système Aquifère de Sfax (Tunisie), Thèse Doctorat," Université de Tunis II, 2000.

[24] M. Gouasmia, "Etude Géophysique des Potentialités Hydrauliques au SW de la Région de Gafsa. Thèse Doctorat

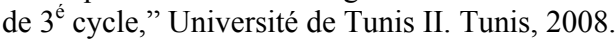

[25] N. Kachouri, “Contribution à 1'Etude Hydrogéologique du Bassin de Moulares-Tamerza, Thèse Doctorat de $3^{\mathrm{e}}$ Cycle," Université de Bordeaux III, 1988.

[26] M. Ricolvi, "Etude Hydrogéologique du Bassin de Moularès-Redeyef," DRES, Serv.géol et rech.Cie des phosphates, 1977. 